\title{
Debriefing evaluation in nursing clinical simulation: a cross-sectional study
}

\author{
Avaliação do debriefing na simulação clínica em enfermagem: um estudo transversal \\ Evaluación del debriefing en la simulación clínica en enfermería: un estudio transversal
}

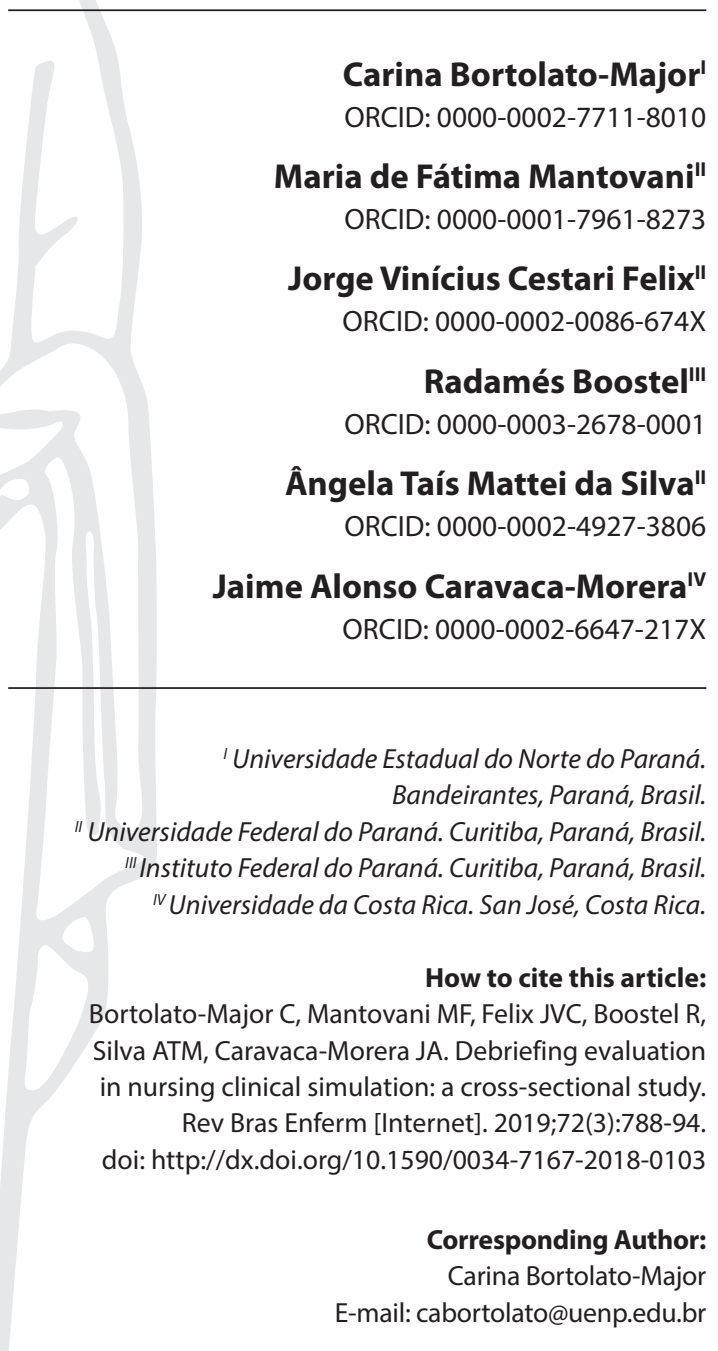

Submission: 03-06-2018 Approval: 03-09-2019

\begin{abstract}
Objective: Evaluate the contribution of debriefing after clinical simulations for nursing students. Method: Quantitative study, conducted with 35 nursing students who participated in five clinical simulation scenarios with planned debriefings based on the model of the National League Nursing/Jeffries Simulation Theory. After the fifth scenario, students answered the Debriefing Evaluation Scale associated with the Simulation. Results: The items evaluated involved the psychosocial, cognitive, and affective values, and within a scale from one to five, the highest mean was found in cognitive value with $4.23( \pm 0.56)$ points, then in psychosocial value with $3.77( \pm 0.53)$, and finally in affective value with $3.71( \pm 0.63)$ points. Conclusion: The debriefing conducted after the clinical simulation scenarios was a reflective exercise that contributed to the student integrating multiple knowledges in affective, cognitive and psychosocial values, and thus develop the competencies required.

Descriptors: Simulation; Thinking; Clinical Competence; Learning; Nursing Students.
\end{abstract}

\section{RESUMO}

Objetivo: Avaliar a contribuição do debriefing após as simulações clínicas para estudantes de enfermagem. Método: Estudo quantitativo, realizado com 35 estudantes de enfermagem que participaram de cinco cenários de simulação clínica com debriefings planejados a partir do modelo da National League Nursing/Jeffries Simulation Theory. Após o quinto cenário, os estudantes responderam a Escala de Avaliação do Debriefing associado à Simulação. Resultados: Os itens avaliados envolveram os valores psicossocial, cognitivo e afetivo, sendo que dentro de uma escala de um a cinco, a maior média foi no valor cognitivo com 4,23 $( \pm 0,56)$ pontos, em seguida no psicossocial com 3,77 $( \pm 0,53)$ e por último no valor afetivo com 3,71 $(+0,63)$ pontos. Conclusão: $O$ debriefing conduzido após os cenários de simulação clínica foi um exercício reflexivo que contribuiu para o estudante integrar saberes múltiplos nos valores afetivo, cognitivo e psicossocial, e assim desenvolver as competências requeridas.

Descritores: Simulação; Pensamento; Competência Clínica; Aprendizagem; Estudantes de Enfermagem.

\section{RESUMEN}

Objetivo: Evaluar la contribución del debriefing después de las simulaciones clínicas para los estudiantes de enfermería. Métodos: Estudio cuantitativo, realizado con 35 estudiantes de enfermería que participaron de cinco escenarios de simulación clínica con debriefings planificados a partir del modelo de National League Nursing/Jeffries Simulation Theory. Después del quinto escenario, los estudiantes respondieron a la Escala de Evaluación del Debriefing relacionada a la simulación. Resultados: Los elementos evaluados incluyeron los valores psicosociales, cognitivos y afectivos, siendo que en la escala de 1 a 5 se obtuvo la mayor media en el valor cognitivo con $4,23( \pm 0,56)$ puntos, luego el psicosocial con 3,77 $( \pm 0,53)$ y, por último, en el valor afectivo con $3,71( \pm 0,63)$ puntos. Conclusión: El debriefing evaluado después de los escenarios de simulación clínica fue un ejercicio que contribuyó al estudiante a integrar conocimientos múltiples en los valores afectivo, cognitivo y psicosocial, y así desarrollar las competencias requeridas.

Descriptores: Simulación; Pensamiento; Competencia Clínica; Aprendizaje; Estudiantes de Enfermería. 
Debriefing evaluation in nursing clinical simulation: a cross-sectional study Bortolato-Major C, Mantovani MF, Felix JVC, Boostel R, Silva ATM, Caravaca-Morera JA

\section{INTRODUCTION}

Clinical simulation is a teaching and learning strategy that enables students to experience simple or complex situations in safe environments prior to actual practice. This must be guided by theoretical models that direct the facilitator to plan, implement and evaluate the activities.

In Nursing, the most widely used model is the National League Nursing/Jeffries Simulation Theory, which advocates the conduct of simulation based on the following characteristics: objectives, fidelity, problem solving, support to student, and debriefing ${ }^{(1-2)}$.

All characteristics of the simulation design are important; however, the debriefing is considered to be the central component of this strategy ${ }^{(3)}$. It should be conducted based on the learning objectives established before execution of the simulated scenario, in order to encourage critical, creative and reflective thinking of students ${ }^{(4)}$.

During the debriefing students are encouraged/invited to express their thoughts, feelings, talk about doubts, uncertainties and limitations in their capacity to take action, self-evaluate their actions, decisions, communication and attitudes, and thus learn with their own experiences and with those of their peers ${ }^{(2)}$.

It is recommended that the debriefing is conducted in a structured manner and contributes to the student's learning ${ }^{(5)}$. Thus, it can be conducted "without judgment", "with judgment", or with "good judgement". In the first, mistakes made by students are not scored and the good points made are praised. In the second, the facilitator directly exposes the mistake and asks "why" the procedure or action was performed in this way, and not in the way that he considers the ideal. In the debriefing with "good judgment", the facilitator verbalizes the activity observed while inviting students to express themselves actively, thus valuing the students' point of view and processing together the mistakes made as a learning opportunity; therefore, there is critical and constructive judgment that favors reflective thinking ${ }^{(6)}$.

A thorough debriefing, without intimidation or without adopting an extremely passive posture, promotes reflection, encourages students to analyze their practice and think on how to hone their skills for nursing practice ${ }^{(6)}$. Reflection is an essential element in the development of professional competencies and implies assimilating knowledge, skills and attitudes with pre-existing knowledge $^{(7)}$.

The development of the debriefing should be based on reflection, through creativity, active involvement, conscious selfevaluation and effective guidance of an experienced facilitator ${ }^{(7)}$. This as irrefutable consequence of that success of debriefing lies in the facilitator's sensitivity and capacity to understand and guide the discussion for reflective thinking so that students spontaneously recognize and verbalize their failures and with that reach the result expected by both protagonists of the process, which is learning and behavior change $\mathrm{e}^{(1-8)}$.

In view of the importance of debriefing after a clinical simulation scenario and considering that this teaching-learning strategy is expanding, studies that evaluate the contribution of debriefing to nursing student training may assist educators to refine this practice.

\section{OBJECTIVE}

Evaluate the contribution of debriefing after clinical simulations for nursing students.

\section{METHODOLOGY}

\section{Ethical aspects}

The research was approved by the Research Ethics Committee. All ethical precepts contained in Resolution 466/2012 of the National Health Council have been complied with. And the use of the scale was authorized by the authors responsible for the construction and validation.

\section{Study design, location, and period}

Quantitative study, with transversal approach, developed in the high fidelity clinical simulation laboratory of a public university in southern Brazil, in the period from August 2015 to June 2016.

\section{Study population}

The study had participation of 35 nursing students enrolled in the Adult and Elderly Health discipline during the data collection period. Inclusion criteria: undergraduate students in Nursing from a public University in southern Brazil, enrolled in sixth period, during the second half of $2015(n=20)$ and first half of $2016(n=15)$. Exclusion criteria: students having degree in health with competence for physical examination, for considering that this prior knowledge could favor the performance of participants in the simulation scenarios. This was self-reported and evaluated with questions at the time of the invitation to participate in the research.

\section{Study protocol}

Students participated in five clinical simulation scenarios, which were planned and developed by the researchers, tested and validated by students from the same period of graduation, in semester prior to the beginning of data collection, and were part of a compulsory discipline of undergraduate nursing program. The themes included stroke, congestive heart failure, arrhythmias, basic life support and advanced life support. The contents were based on the Advanced Cardiology Life Support (ACLS) ${ }^{(9-10)}$ based on which we selected and prepared the set of knowledge, skills and attitudes to be acquired. The objectives of each scenario are presented in Chart 1.

The scenarios were planned, implemented and evaluated based on the simulation model of the National League Nursing/Jeffries Simulation Theory ${ }^{(1-2)}$ and conducted in the high fidelity adult patient simulator, CIVIAM ${ }^{\circledR}$ METIman model. In each encounter, there was randomization of the teams, through the distribution of envelopes containing numbers which allowed for the division of participants into teams of five members. All students participated in the proposed simulations. The scenarios were conducted by the main author and by members of the research team, which received training prior to the development of each scenario. 
Chart 1 - Objectives of the clinical simulation scenarios and number of participants. Curitiba, PR, 2017

\begin{tabular}{|c|c|c|}
\hline \multirow{2}{*}{ Scenarios* } & \multicolumn{2}{|c|}{ Objectives } \\
\hline & Non-technical skills & Technical skills \\
\hline Stroke & $\begin{array}{l}\text { Know the environ- } \\
\text { ment; anticipate and } \\
\text { plan; designate leader- } \\
\text { ship; distribute the } \\
\text { workload; communi- } \\
\text { cate effectively. }\end{array}$ & $\begin{array}{l}\text { Perform directed neu- } \\
\text { rological evaluation; } \\
\text { assess vital signs and plan } \\
\text { carefully; determine heart } \\
\text { rate and associate it to the } \\
\text { etiology of sloping rima } \\
\text { oris; observe signs and } \\
\text { symptoms and intervene; } \\
\text { administer medications } \\
\text { according to protocol. }\end{array}$ \\
\hline $\begin{array}{l}\text { Congestive } \\
\text { heart failure } \\
\text { with ar- } \\
\text { rhythmias }\end{array}$ & $\begin{array}{l}\text { Designate leadership; } \\
\text { distribute the work- } \\
\text { load and communicate } \\
\text { effectively. }\end{array}$ & $\begin{array}{l}\text { Assess vital signs and } \\
\text { intervene; conduct targeted } \\
\text { physical examination and } \\
\text { intervene; request additional } \\
\text { tests, if necessary; determine } \\
\text { heart rate; administer medi- } \\
\text { cation according to medical } \\
\text { prescription. }\end{array}$ \\
\hline $\begin{array}{l}\text { Basic life } \\
\text { support }\end{array}$ & $\begin{array}{l}\text { Designate leader- } \\
\text { ship; distribute the } \\
\text { workload; anticipate } \\
\text { and plan; communicate } \\
\text { effectively; mobilize } \\
\text { resources. }\end{array}$ & $\begin{array}{l}\text { Perform basic life support } \\
\text { care according to the } \\
\text { American Heart Associa- } \\
\text { tion protocol. }\end{array}$ \\
\hline $\begin{array}{l}\text { Advanced } \\
\text { life sup- } \\
\text { port I }\end{array}$ & $\begin{array}{l}\text { Designate leadership } \\
\text { and promote team } \\
\text { work; distribute the } \\
\text { workload with well- } \\
\text { defined functions; } \\
\text { anticipate and plan; } \\
\text { mobilize resources; } \\
\text { communicate in closed } \\
\text { loop; adopt clear and } \\
\text { targeted messages. }\end{array}$ & $\begin{array}{l}\text { Perform advanced life sup- } \\
\text { port care according to the } \\
\text { American Heart Associa- } \\
\text { tion protocol. }\end{array}$ \\
\hline $\begin{array}{l}\text { Advanced } \\
\text { life sup- } \\
\text { port II }\end{array}$ & $\begin{array}{l}\text { Designate leadership } \\
\text { and promote team } \\
\text { work; distribute the } \\
\text { workload with well- } \\
\text { defined functions; } \\
\text { anticipate and plan; } \\
\text { mobilize resources; } \\
\text { communicate in closed } \\
\text { loop and adopt clear } \\
\text { and targeted mes- } \\
\text { sages; share knowledge; } \\
\text { perform constructive } \\
\text { intervention; know own } \\
\text { limitations. }\end{array}$ & $\begin{array}{l}\text { Perform ALS service } \\
\text { according to American } \\
\text { Heart Association protocol; } \\
\text { start care upon return of } \\
\text { spontaneous circulation } \\
\text { and reassess service. }\end{array}$ \\
\hline
\end{tabular}

* The total of 35 students participated in all scenarios. During the second semester of 2015, the 20 students were divided into four teams of five participants. In the first semester of 2016 , the 15 students were divided into three teams of five participants.

The simulations occurred in three phases: the briefing, averaging seven minutes, at which point the characteristics of the simulator were reviewed and we presented the goals of the scenario; the experience of the simulation (10 minutes), and the debriefing, conducted with good judgment, which lasted on average 15 minutes, according to the needs of each team, and was conducted in all scenarios by the lead researcher, who had experience and training for debriefing in simulation.
The data were collected after the end of the fifth simulation meeting. For evaluation of the five times, students answered the Debriefing Evaluation Scale associated with the Simulation, which was constructed and validated for Portuguese ${ }^{(11)}$. Its reliability was measured, showing the Cronbach's alpha coefficient of 0.899 .

The scale contains 34 self-filling, five-point, Likert-type items: disagree completely (1); disagree (2); neither agree nor disagree (3); agree (4), and agree completely (5). Concerning the analysis, items can be evaluated individually or in three dimensions, including "psychosocial value", which refers to psychological and social aspects inherent in the simulation; "cognitive value" attributes the consolidation of knowledge through discussion during the debriefing; and "affective value", which relates to feelings or affections.

\section{Analysis of results and statistics}

The data were tabulated in Microsoft Excel ${ }^{\circledast}$ spreadsheet and analyzed descriptively, by absolute and relative frequency, using Statistical Package for the Social Sciences (SPSS ${ }^{\circledR}$ ) version 22.0, and presented in tables.

\section{RESULTS}

Of the total of 35 participants, 29 (90.6\%) were female, 16 (45.7\%) were aged 22-24 years, 34 (97.1\%) did not have another degree, 26 (74.2\%) had not attended nursing assistant or nursing technician courses, and 34 (97.1\%) were currently attending the Nursing degree adult and elderly Health discipline for the first time.

As for the Debriefing Evaluation Scale associated with the Simulation, the overall average of agreement was 3.9 points, being higher for cognitive value (Table 1).

Table 1 - Minimum value, maximum value, mean, and standard deviation of the debriefing factors associated with the simulation. Curitiba, PR, Brazil, 2017

\begin{tabular}{|c|c|c|c|c|}
\hline DIMENSIONS & MIN* & MAX† & $M \pm$ & SD§ \\
\hline Factor 1 - Psychosocial value & 2,2 & 5,0 & 3,77 &, 56 \\
\hline Factor 2 - Cognitive value & 2,6 & 5,0 & 4,23 &, 53 \\
\hline Factor 3 - Affective value & 2,5 & 5,0 & 3,71 & ,63 \\
\hline
\end{tabular}

Considering the items of the scale, for the psychosocial dimension, it was found that the students showed agreement of $85.7 \%$ in items 17, 23 and 26; in item 19 with $88.5 \%$; in item 27 with $88.6 \%$ and in item $30,82.8 \%$. For the cognitive dimension items 3, 6 and 7 showed agreement of $97.1 \%$ and items 12 and $13,91.4 \%$. In the affective dimension items 18 and 20, whose positive answers are 1 - "completely disagree" and 2 - "disagree", were those that obtained the highest frequencies, representing $85.7 \%$ and $82.8 \%$ of disagreement, respectively (Chart 2).

In relation to the overall reliability of the Debriefing Evaluation Scale associated with the Simulation, the Cronbach's alpha value, in this research, was 0.857 . In analyzing the Alpha for each dimension, we obtained the value of 0.887 for psychosocial value, 0.923 for cognitive value, and 0.898 for affective value. 
Debriefing evaluation in nursing clinical simulation: a cross-sectional study Bortolato-Major C, Mantovani MF, Felix JVC, Boostel R, Silva ATM, Caravaca-Morera JA.

Chart 2 - Distribution of items of the Debriefing Evaluation Scale associated with the Simulation according to the dimensions. Curitiba, PR, Brazil, 2017

\begin{tabular}{|c|c|c|c|c|c|c|c|c|c|c|c|}
\hline \multirow{2}{*}{ 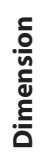 } & \multirow{2}{*}{ ITENS } & \multicolumn{2}{|c|}{$\begin{array}{l}\text { Completely } \\
\text { disagree }\end{array}$} & \multicolumn{2}{|c|}{ Disagree } & \multicolumn{2}{|c|}{ Indifferent } & \multicolumn{2}{|c|}{ Agree } & \multicolumn{2}{|c|}{$\begin{array}{l}\text { Completely } \\
\text { agree }\end{array}$} \\
\hline & & $\mathbf{N}$ & $\%$ & $\mathbf{N}$ & $\%$ & $\mathbf{N}$ & $\%$ & $\mathbf{N}$ & $\%$ & $\mathbf{N}$ & $\%$ \\
\hline \multirow{13}{*}{ 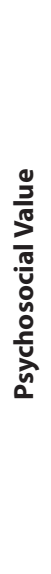 } & 16 Increase my self-confidence & & & & & 12 & 34.3 & 14 & 40 & 9 & 25.7 \\
\hline & 17 Develop leadership competencies & & & 1 & 2.9 & 4 & 11.4 & 21 & 60 & 9 & 25.7 \\
\hline & 19 Increase the potential for teamwork & & & 1 & 2.9 & 3 & 8.6 & 18 & 51.4 & 13 & 37.1 \\
\hline & 21 Feel accomplished & 1 & 2.9 & 3 & 8.6 & 23 & 65.7 & 4 & 11.4 & 4 & 11.4 \\
\hline & 22 Reinforce my initiative in future situations & & & 1 & 2.9 & 6 & 17.1 & 17 & 48.6 & 11 & 31.4 \\
\hline & 23 Develop the care relationship & 2 & 5.7 & & & 3 & 8.6 & 18 & 51.4 & 12 & 34.3 \\
\hline & 25 Reinforce my autonomy to act as a future nurse & & & & & 7 & 20 & 17 & 48.6 & 11 & 31.4 \\
\hline & 26 Trace difficulties in my performance & 1 & 2.9 & & & 4 & 11.4 & 21 & 60 & 9 & 25.7 \\
\hline & 27 Promote self-awareness (know one's own emotions) & & & & & 4 & 11.4 & 18 & 51.4 & 13 & 37.2 \\
\hline & 28 Feel in the center of the educational process & 2 & 5.7 & 7 & 20 & 7 & 20 & 14 & 40 & 5 & 14.3 \\
\hline & 30 Improve my ability to manage emotions & & & 1 & 2.9 & 5 & 14.3 & 21 & 60 & 8 & 22.8 \\
\hline & $\begin{array}{l}32 \text { Feel proud for being able to execute many interventions } \\
\text { correctly }\end{array}$ & & & 2 & 5.7 & 8 & 22.9 & 22 & 62.8 & 3 & 8.6 \\
\hline & $\begin{array}{l}33 \text { Feel that the professor has genuine interest in my professional } \\
\text { development }\end{array}$ & 1 & 2.9 & 2 & 5.7 & 8 & 22.9 & 16 & 45.6 & 8 & 22.9 \\
\hline \multirow{9}{*}{ 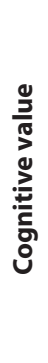 } & 1 Structure my thought & & & 1 & 2.9 & 5 & 14.3 & 17 & 48.6 & 12 & 34.2 \\
\hline & 3 Learn more & & & 1 & 2.9 & & & 21 & 60 & 13 & 37.1 \\
\hline & 4 Focus on the important aspects of performance & & & & & 5 & 14.3 & 18 & 51.4 & 12 & 34.3 \\
\hline & 6 Reflect on my competencies & & & & & 1 & 2.9 & 24 & 68.5 & 10 & 28.6 \\
\hline & 7 Determine priorities in the practice & & & & & 1 & 2.9 & 17 & 48.6 & 17 & 48.5 \\
\hline & 8 Better determine the resources to use in the practice & & & 1 & 2.9 & 4 & 11 & 19 & 53 & 11 & 33.1 \\
\hline & 10 Deepen specific knowledge related to the practice & & & 1 & 2.9 & 4 & 11.4 & 17 & 48.6 & 13 & 37.1 \\
\hline & 12 Trace aspects that I should improve in future practice & & & 1 & 2.9 & 2 & 5.7 & 19 & 54.3 & 13 & 37.1 \\
\hline & 13 Develop skills for making good decisions & & & 1 & 2.9 & 2 & 5.7 & 21 & 60 & 11 & 31.4 \\
\hline \multirow{12}{*}{ 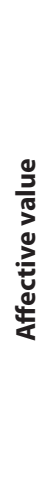 } & 2 Feel ashamed in front of colleagues for my mistakes & 10 & 28.5 & 11 & 31.4 & 8 & 22.9 & 5 & 14.3 & 1 & 2.9 \\
\hline & 5 Make me very anxious/stressed out & 4 & 11 & 12 & 34.3 & 9 & 25.7 & 7 & 20.4 & 3 & 8.6 \\
\hline & 9 Feel humiliated in front of others & 12 & 34.3 & 14 & 40 & 8 & 22.8 & 1 & 2.9 & & \\
\hline & $\begin{array}{l}11 \text { Be in panic at the thought of having to act again in a similar } \\
\text { situation }\end{array}$ & 10 & 28.6 & 13 & 37.1 & 9 & 25.7 & 2 & 5.7 & 1 & 2.9 \\
\hline & 14 Create conflicts in the group & 8 & 22.8 & 19 & 54.3 & 1 & 2.9 & 3 & 8.6 & 4 & 11.4 \\
\hline & 15 Not want to participate in any simulation & 8 & 22.8 & 15 & 42.9 & 9 & 25.7 & 2 & 5.7 & 1 & 2.9 \\
\hline & 18 Feel misunderstood & 9 & 25.7 & 21 & 60 & 4 & 11.4 & 1 & 2.9 & & \\
\hline & 20 Feel disrespected & 15 & 42.8 & 13 & 40 & 5 & 14.3 & 1 & 2.9 & & \\
\hline & 24 I feel it was a waste of time & 11 & 31.5 & 16 & 45.7 & 6 & 17.1 & & & 2 & 5.7 \\
\hline & 29 Be afraid to act in similar situations in the future & 10 & 28.6 & 17 & 48.5 & 5 & 14.3 & 2 & 5.7 & 1 & 2.9 \\
\hline & 31 Block my reasoning & 10 & 28.6 & 16 & 45.7 & 7 & 20 & 2 & 5.7 & & \\
\hline & 34 Scramble my ideas about the practice & 13 & 37.1 & 10 & 28.6 & 9 & 25.7 & 2 & 5.7 & 1 & 2.9 \\
\hline
\end{tabular}

\section{DISCUSSION}

The Debriefing Evaluation Scale associated with the Simulation applied to nursing students of a University in the South of Brazil, after participating in five simulation scenarios with high fidelity and complexity, obtained Cronbach's alpha results of 0.857 , which shows good internal consistency, similar to the research that validated the scale ${ }^{(11)}$.

The results found for the three dimensions - psychosocial, cognitive, and affective dimensions - are related with the competencies, general skills, and specific skills recommended in the National Curriculum Guidelines for Graduate Programs in Nursing (DCNE) ${ }^{(12)}$.
Analysis of the psychosocial dimension pointed to a high agreement of students with items 17 - develop leadership competencies, 19 -increase the potential for teamwork, 23 - develop the care relationship, 26 - trace difficulties in my practice, and 27 - promote self-awareness (know one's own limitations).

The high percentage of agreement of item 17 corroborates the DCNE guidelines that emphasize that health professionals should be able to assume leadership, which"involves commitment, responsibility, empathy, ability for decision-making, efficient and effective management"(12). This result may be related with one of the non-technical objectives proposed for the simulation, namely: designate leadership, showing that both the experience of simulation and debriefing contributed to the acquisition of this skill. 
Items 19 and 23 comply with the competencies and skills proposed by the DCNE guidelines, which address the undergraduate curriculum, which should be able to train for the competencies of nursing and multidisciplinary teamwork, interpersonal and dynamic relationships in group ${ }^{(12)}$. In this research, students had the opportunity to experience in practice the teamwork, the distribution of the workload with predefined functions, as well as the planning, resource mobilization, communication and intervention, a fact that may have contributed to the acquisition of the skills outlined in items 19 and 23.

The simulation experience with the debriefing can provide the acquisition of the teamwork competence that involves the integration of distinct kinds of knowledge ${ }^{(13)}$. Team work comprises the kinds of knowledge: act cooperatively, communicate, self-evaluate, reflect, engage, negotiate and act together to solve problems, multiply knowledge and build relational bridges, for example. Professionals that can work in a team are open to a culture of cooperation and acknowledge that the leadership helps to establish priorities and that it can contribute to collective decision-making ${ }^{(13)}$. These conceptions comply with the "learn to coexist" and "learn to live together" concepts also recommended in the DCNE guidelines ${ }^{(12)}$.

Items 26 - trace difficulties in my practice - and 27 - promote self-awareness (know one's own limitations) are associated with the non-technical objectives proposed in the fifth scenario, in which students are expected to recognize their own limitations during the simulation experience.

In the cognitive dimension, items 3 - learn more, 6 - reflect on my competencies, 7 - determine priorities in the practice, 12 - trace aspects that I should improve in future practice, and 13 - develop competencies for correct decision making - were highlighted.

Items 3, 6, and 12 are consistent with the DCNE guidelines by mentioning that the structure of the undergraduate program must ensure critical, reflective and creative education, that encourages students to learn how to learn and to learn how to $\mathrm{do}^{(12)}$, in addition to the competence of "know how to learn and learn how to learn"(14). In these, individuals who know how to "take lessons from experience" take advantage of their practice as an opportunity to obtain knowledge, they do not settle for doing and acting, but are in pursuit of theories and foundation that validate their action.

It is believed that the percentage of agreement in these items $(3,6$, and 12$)$ is related to the opportunity that students had to participate both in the simulation experience, by immersion in clinical care, and in the debriefing, conducted with good judgment and guided by a facilitator, after each simulation scenario, due to fostering reflective thinking and self-monitoring through active involvement.

Corroborating a case study with undergraduate nursing students of a university in the countryside of the state of São Paulo, it was found that students can conduct a critical review of learning and the debriefing was considered a time to express the feelings experienced and an opportunity to reflect on the results of their own actions and to determine the attitudes that impair performance during the simulation ${ }^{(15)}$.

In another study conducted in Portugal with 82 nursing students, these reported that they managed to develop, during the simulation and in the debriefing based on reflection on the nursing practice, professional competencies necessary for the nursing professional practice ${ }^{(16)}$.

The simulation experience with the debriefing is associated with the students' opportunity to develop critical thinking, creativity, reasoning, clinical judgment, and decision-making, with these elements being desired so the nurse can become an expert ${ }^{(1,17)}$.

Item 13 is related to one of the general competencies and skills of the DCNE guidelines, which recommend that the professional should be able to make decisions, to assess, systematize and decide the conducts based on scientific evidence ${ }^{(12)}$, with the "power to act with effectiveness in a situation"(13), and also"knowing how to act pertinently"(14). The capacity to make decisions is consistent with one of the objectives of the scenarios and it can be inferred that it was gradually honed by students during their active participation both in the scenarios as in the debriefing.

The knowing how to act pertinently ${ }^{(14)}$ is observed in professionals who have initiative and take relevant decisions, assuming responsibilities and innovating; these are the ones who make choices, take risks and respond to contingencies, anticipating and predicting the consequences; know how to interpret, understand and how to act before deteriorated situations, and so are able to solve problems. This competence enables the mobilization of knowledge in order to act with relevance to learn how to learn and engage with the context ${ }^{(14)}$.

In general, several authors ${ }^{(18-20)}$ report the benefits of debriefing in the development of students. This study confirms these conclusions and materialize their positive impact on the acquisition of skills for decision-making.

The ability of decision-making and prioritization of actions have been considered fundamental characteristics for nursing students, because they involve a complex cognitive process, that is focused on the analysis of a difficult situation so as to determine action $^{(21)}$. These skills are considered "contextual processes", continuous and evolving, in which the data are collected, interpreted and evaluated for the choice of actions based on evidence ${ }^{(22)}$.

Considering that the decision-making process directly influences the results and, consequently, patient safety, the authors suggest that educators use teaching strategies that foster the development of competence and ability for clinical reasoning and problem solving, thus favoring the improvement of decision-making ${ }^{(21-23)}$.

In this context, the experience report on the implementation of clinical simulation in a discipline o a University in southern Brazil assessed that the debriefing contributed to teamwork, the tracing of weaknesses, ethical behavior, perception of different ways to approach the same clinical context, knowing how to handle one's own mistake, that of a coworker and criticism ${ }^{(24)}$.

In this study, students also had the opportunity to experience these aspects, since in each simulation experience a team member was elected to lead and, during the debriefing, the facilitator was conducted the discussion to the student's reflection on his or her individual decision making and on the decision making as a team. Authors discuss that debriefing after simulation promotes the development of this decision-making ability (20).

In the affective dimension, the results showed that students did not consider that they had been disrespected or misunderstood 
Debriefing evaluation in nursing clinical simulation: a cross-sectional study Bortolato-Major C, Mantovani MF, Felix JVC, Boostel R, Silva ATM, Caravaca-Morera JA.

(items 18 and 20). These findings are consistent with the DCNE guidelines, which propose that the program's pedagogical project should ensure teaching and learning centered on students, with these being active subjects in their training process ${ }^{(12)}$. Therefore, these data suggest that debriefing with good judgement contributed to student development, without humiliation and without offensive judgements. In this type of debriefing, students had a space to organize their reflections on the practice, thus finding new understandings about their practice in the simulation scenario, which will serve for future clinical practice.

It is pointed out that, when the debriefing is mishandled, the entire gain of learning can be impaired. This leads to negative feelings on the part of students, who may show decreased clinical performance and reflective capacity, in addition to difficulties in the relationship with the facilitator ${ }^{(5)}$.

It is observed that were numerous perceived gains for student training, including the acquisition of the reflective thought competence, which was developed during the debriefing. This competence is consistent with the recommendations of the DCNE guidelines, as they indicate that the structure of the program should ensure critical, reflective and creative education, and ensure that the profile of the graduating student leads to a critical and reflective nurse ${ }^{(12)}$.

The debriefing phase after the clinical simulation promotes a reflective learning process with the opportunity to develop multiple skills ${ }^{(2)}$. In this study, these skills are represented in cognitive, affective and psychosocial values.

\section{Study limitations}

The main limitation of this research refers to the number of participants and to the debriefing evaluation only at the end of five simulations, not allowing for monitoring of the evolution of the activity in the course of the simulation.

\section{Contributions to the nursing field}

It is believed that this manuscript contributes to the planning of clinical simulation practice in nursing student training with regard to the debriefing step, since this involves discussion and reflection oriented by the objectives of the scenarios and these are consistent with the competencies and skills established by the DCNE guidelines.

\section{CONCLUSION}

Debriefing is a simulation experience in which there is analysis or reflection guided by a facilitator, that fosters self-assessment, reflective and significant learning, reflection on the experience, discussion on the objectives of the learning, reinforcement of good practices, learning about the mistakes, the strengthening of decision-making and teamwork.

Therefore, it should be a time of discovery, shared learning between students and the facilitator. It should go beyond assessment, in order to ensure assurance, confidence and encouragement throughout the learning process.

The debriefing conducted with good judgment, after the clinical simulation scenarios, was a reflective exercise that contributed to the student integrating multiple knowledges in affective, cognitive and psychosocial values, and thus developing the competencies required.

The debriefing after the clinical simulations contributed to the development of competencies/skills with regard to the three dimensions, and items related to leadership, care relationship and difficulties in practice, of the psychosocial dimension, as well as learn more, reflect on competencies, and determine priorities, of the cognitive dimension, showed the highest rates of agreement. Concerning the affective dimension, items that addressed aspects related to feeling misunderstood and disrespected obtained the highest disagreement.

The Debriefing Evaluation Scale associated with the Simulation enabled the facilitators to know, from the perspective of students, its importance to the teaching-learning process, which reinforces the need to always evaluate it and conduct it according to a model that provides its foundation.

\section{FOMENTO / AGRADECIMENTO}

Coordenação de Aperfeiçoamento de Pessoal de Nível Superior (CAPES).

\section{REFERENCES}

1. Jeffries PR. Simulation in nursing education: from conceptualization to evaluation. 2nd ed. New York: National League for Nursing; 2012.

2. Jeffries PR. The NLN Jeffries simulation theory. Wolters Kluwer: National League for Nursing; 2016.

3. Almeida RGS, Mazzo A, Martins JCA, Coutinho VRD, Jorge BM, Mendes IAC. [Validation to Portuguese of the Debriefing Experience Scale]. Rev Bras Enferm [Internet]. 2016 [cited 2017 Sept 11];69(4):658-64. Available from: http://www.scielo.br/pdf/reben/v69n4/en_0034-7167reben-69-04-0705.pdf Portuguese.

4. Gore T, Thomson W. Use of simulation in undergraduate and graduate education. AACN Adv Crit Care [Internet]. 2016 [cited 2017 Feb 10];27(1):86-95. Available from: www.ncbi.nlm.nih.gov/pubmed/26909458

5. Palaganas JC, Fey M, Simon R. Structured debriefing in simulation-based education. AACN Adv Crit Care [Internet]. 2016 [cited 2017 Oct 5];27(1):78-85. Available from: https://www.ncbi.nlm.nih.gov/pubmed/26909457

6. Rudolph JW, Simon R, Dufresne RL, Raemer DB. There's no such thing as "nonjudgmental" debriefing: a theory and method for debriefing with good judgment. Simul Healthc [Internet]. 2006 [cited 2017 Nov 18];1(1):49-55. Available from: www.ncbi.nlm.nih.gov/ pubmed/19088574 
Debriefing evaluation in nursing clinical simulation: a cross-sectional study Bortolato-Major C, Mantovani MF, Felix JVC, Boostel R, Silva ATM, Caravaca-Morera JA.

7. Decker S, Fey M, Sideras S, Caballero S, Rockstraw L, Boese T, et al. Standards of best practice: simulation standard Vl: the debriefing process. Clin Simul Nurs [Internet]. 2013 [cited 2017 Nov 12];9(6):26-9. Available from: http://www.nursingsimulation.org/article/ S1876-1399\%2813\%2900079-0/abstract

8. Martins JCA, Mazzo A, Baptista RCN, Coutinho VRD, Godoy S, Mendes IAC, et al. [The simulated clinical experience in nursing education: a historical review]. Acta Paul Enferm [Internet]. 2012 [cited 2017 Oct 29];25(4):619-25. Available from: http://www.scielo.br/pdf/ape/v25n4/ en_22.pdf Portuguese.

9. American Heart Association. Highlights of the 2015 American Heart Association Guidelines Update for CPR and ECC. [Internet]. 2015 [cited 2017 Oct 29]. Available from: https://eccguidelines.heart.org/wp-content/uploads/2015/10/2015-AHA-Guidelines-Highlights-English.pdf

10. ACLS Suporte avançado de via em cardiologia. 4th ed. Rio de Janeiro: Elsevier; 2012. 424 p.

11. Coutinho VRD, Martins JCA, Pereira MFCR. [Construction and Validation of the Simulation Debriefing Assessment Scale]. Rev Enf Ref [Internet]. 2014 [cited 2017 Oct 5];4(2):41-50. Available from: http://www.scielo.mec.pt/pdf/ref/vserlVn2/serlVn2a05.pdf Portuguese.

12. Cofen: Conselho Federal de Enfermagem. Resolução CNE/CES no 3, de 7 de novembro de 2001. Institui Diretrizes Curriculares Nacionais do Curso de Graduação em Enfermagem [Internet]. Diário Oficial da União: República Federativa do Brasil [Internet]. 2011 Nov 11 [cited 2017 Oct 5];1:59. Available from: http://www.cofen.gov.br/wp-content/uploads/2012/03/resolucao_CNE_CES_3_2001Diretrizes_Nacionais_ Curso_Graduacao_Enfermagem.pdf

13. Perrenoud P. Desenvolver competências ou ensinar saberes: a escola que prepara para a vida. Porto Alegre: Penso; 2013.

14. Le Boterf G. Desenvolvendo a competência dos profissionais. 3rd ed. Porto Alegre: Artmed; 2003.

15. Teixeira CRS, Pereira MCA, Kusumota L, Gaioso VP, Mello CL, Carvalho EC. Evaluation of nursing students about learning with clinical simulation. Rev Bras Enferm [Internet]. 2015 [cited 2017 Dec 4];68(2):311-9. Available from: http://www.scielo.br/pdf/reben/v68n2/00347167-reben-68-02-0311.pdf

16. Presado MHCV, Colaço S, Rafael H, Baixinho CL, Félix I, Saraiva C, et al. Aprender com a simulação de alta fidelidade. Cienc Saude Colet [Internet]. 2018 [cited 2019 Jan 19];23(1):51-9. Available from: http://www.scielo.br/pdf/csc/v23n1/1413-8123-csc-23-01-0051.pdf

17. Lasater K. Clinical judgment: the last frontier for evaluation. Nurse Educ Pract [Internet]. 2011 [cited 2017 Oct 25];11(2):86-92. Available from: www.ncbi.nlm.nih.gov/pubmed/21212021

18. Jersby MA, Van-Schaik P, Green S, Nacheva-Skopalik L. The use of multiple-criteria decision-making theory to measure students' perceptions of high-fidelity simulation. BMJ Sim Technol Enhan Lear [Internet]. 2017 [cited 2017 Sept 12];3(3):88-93. Available from: http://dx.doi. org/10.1136/bmjstel-2016-000167

19. Bucknall TK, Forbes H, Phillips NM, Hewitt NA, Cooper S, Bogossian F. An analysis of nursing students' decision-making in teams during simulations of acute patient deterioration. J Adv Nurs [Internet]. 2016 [cited 2017 Nov 15];72(10):2482-94. Available from: www.ncbi.nlm. nih.gov/pubmed/27265550

20. McCallum J, Ness V, Price T. Exploring nursing students' decision-making skills whilst in a Second Life clinical simulation laboratory. Nurse Educ Today [Internet]. 2011 [cited 2017 Oct 5];31(7):699-704. Available from: www.ncbi.nlm.nih.gov/pubmed/20807671

21. Tabhet M, Taha EES, Abood SA, Morsy SR. The effect of problem-based learning on nursing students' decision making skills and styles. J Nurs Educ Pract [Internet]. 2017 [cited 2017 Oct 5];7(6):108-16. Available from: http://www.sciedupress.com/journal/index.php/jnep/article/ view/10355/6745

22. Tiffen J, Corbridge SJ, Slimmer L. Enhancing clinical decision making: development of a contiguous definition and conceptual framework. J Prof Nurs [Internet]. 2014 [cited 2017 Oct 5];30(5):399-405. Available from: www.ncbi.nlm.nih.gov/pubmed/25223288

23. Johansen ML, O'Brien JL. Decision making in nursing practice: a concept analysis. Nurs Forum [Internet]. 2016 [cited 2017 Nov 22];51(1):408. Available from: https://www.ncbi.nlm.nih.gov/pubmed/25639525

24. Oliveira SN, Massaroli A, Martini JG, Rodrigues J. [From theory to practice, operating the clinical simulation in Nursing teaching]. Rev Bras Enferm [Internet]. 2018 [cited 2017 Nov 22];71(Suppl 4):1896-903. Available from: http://www.scielo.br/pdf/reben/v71s4/pt_0034-7167reben-71-s4-1791.pdf Portuguese. 